\title{
Research on Tax Collection and Management System of E-Commerce
}

\author{
Aizhen Li \\ School of Law, Boston University, Boston, USA \\ Email: liaizhen1021@163.com
}

How to cite this paper: Li, A. (2018) Research on Tax Collection and Management System of E-Commerce. American Journal of Industrial and Business Management, 8, 2256-2266.

https://doi.org/10.4236/ajibm.2018.811150

Received: November 8, 2018

Accepted: November 26, 2018

Published: November 29, 2018

Copyright $\odot 2018$ by author and Scientific Research Publishing Inc. This work is licensed under the Creative Commons Attribution International License (CC BY 4.0).

http://creativecommons.org/licenses/by/4.0/

(c) (i) Open Access

\begin{abstract}
With the development of science and technology, the technology represented by the Internet and modern communication is gradually changing the whole society. The traditional trading methods and advanced Internet technology create a new way of transaction-electronic commerce transaction. While electronic commerce brings the efficiency and wealth to the human society, it also takes the effect on the tax implications. The e-commerce has raised a serious challenge to the current tax policy, tax system and international tax issues. In order to protect the financial interests, different countries demonstrate different attitudes and propose corresponding tax measures to adapt and improve the development of e-commerce. In China, electronic commerce has led to some serious problems, such as the difficulties in tax collection and management, and growing of the tax revenue loss. Currently, e-commerce guidance policy is staying on the macro-level. Without specific tax system, there will be inevitably results of the loss of state revenue and the block of fair competition between e-commerce and traditional transactions if our country does not introduce the reasonable e-commerce-related tax policies and measures. For the issue of China's e-commerce taxation, this paper discusses the relationship between e-commerce and economic growth and tax revenue on the basis of foreign experience in tax policy, and puts forward tax policy advice of our country's electronic commerce.
\end{abstract}

\section{Keywords}

Electronic Commerce, Tax Revenue, Tax Policy, International Experience

\section{Introduction}

It is the objective of this paper to demonstrate the need for a national solution to the issue of e-commerce taxation within the China through a sound e-commerce 
policy. First, the paper mainly introduces the connotation, classification and characteristics of e-commerce. The second chapter is an in-depth analysis of the impact of e-commerce on China's taxation principles, taxation legal systems, tax collection and management. The third chapter compares and analyzes some e-commerce taxation policies and measures taken by developed countries and developing countries. It is hoped that some experiences and lessons can be learned from the taxation cases of these countries in order to improve the management of China's e-commerce taxation. Finally, through the systematic analysis of the previous chapters and combining with the current situation of China, the fourth chapter puts forward some suggestions on the establishment of e-commerce tax system in China.

\section{E-Commerce Overview}

\subsection{The Concept of E-Commerce}

E-commerce, also known as electronic commerce or internet commerce, refers to the buying and selling of goods or services using the internet, and the transfer of money and data to execute these transactions. Ecommerce is often used to refer to the sale of physical products online, but it can also describe any kind of commercial transaction that is facilitated through the internet. Its essence is the direct or indirect way of trading in goods, currencies and services based on digital networks. Broadly speaking, E-commerce refers to the application of electronic and information technology for economic and trade activities. It includes not only goods or business transactions through the Internet, but also the use of computers, telephones, faxes, and networks, which all kinds of business activities carried out by various electronic media. The narrow sense of e-commerce refers to the business transaction activities realized by the Internet, and the transaction objects may be tangible products and services, such as books, clothing, daily necessities, etc., or some intangibles products including news, audiovisual products, distance learning, online consulting, software, databases, etc. The e-commerce taxation issues discussed in this article are in the narrow sense of e-commerce [1].

\subsection{Classification of E-Commerce}

E-commerce has undergone diversity changes in the process of development. According to different classification criteria, e-commerce can be divided into different categories.

According to the different operation modes of business activities, e-commerce includes pure electronic commerce and partial e-commerce. Pure e-commerce refers to e-commerce that can be realized on the network through the entire business process such as information flow and capital flow during the transaction process. Partial e-commerce refers to the transaction behavior or process that needs to rely on some external factors to complete the entire transaction, and cannot rely solely on the network to complete. 
In accordance with the information network scope of electronic transactions, e-commerce includes three categories: local e-commerce, remote domestic e-commerce and global e-commerce. Local e-commerce refers to the e-commerce activities carried out by both parties in the local area and the both parties will use the local information network. Thus the geographical scope of the transaction is small. Remote domestic e-commerce refers to online electronic trading activities conducted in the country, instead of in the local area. The requirements for hardware, software and technology are more demanding, and the geographical scope of transactions is relatively large. Global e-commerce refers to the electronic trading activities carried out through the Internet on a global scale. Its business content is complex, and it involves multiple systems such as import and export systems, customs systems, banking financial systems, and tax systems in both countries.

In terms of the content of e-commerce activities, e-commerce can be divided direct e-commerce and indirect e-commerce. Direct e-commerce refers to a transaction activity in which a merchant does not need to transfer an intangible goods or services through a material form or a specific package, directly transmitting the digitized products or services to consumers online, and charging a certain fee. Indirect e-commerce refers to physical product transactions conducted online. However, it involved in online transactions can only be ordering, payment or partial after-sales service. It only speeds up the circulation of goods or funds through the Internet, but it is essentially a traditional way of trading.

Depending on who is involved in the transaction, e-commerce activities include inter-enterprise (B2B), business-to-consumer (B2C), business-to-government (B2G), and consumer-to-consumer (C2C). The B2B mode refers to the electronic trade mode in which enterprises exchange and transfer data and information through the Internet to complete business activities such as online ordering, purchasing, and marketing. It is not only efficient, but also reduces production costs and shortens the production process. The B2C model refers to the commercial retail model in which enterprises directly sell consumers' products or services through the Internet, also known as the online retail model. To a certain extent, this model has expanded the scope of traditional sales operations. With the gradual maturity of the e-commerce environment, online transactions will inevitably become more frequent, and the traditional trading mode will be affected to a certain extent. The B2G model refers to an operational mode of e-commerce transaction activities between enterprises and government agencies through the network. For example, online procurement, electronic tax filing, online property rights trading, etc. all belong to the $\mathrm{B} 2 \mathrm{G}$ model, which can contain many things between the company and the government. The $\mathrm{C} 2 \mathrm{C}$ model refers to online transactions conducted by consumers through the Internet, such as online auctions, item exchanges, and the like. Its trading entities are individuals, not including companies, so it is very difficult to determine their tax status in this environment. In addition, its trading process is fully dependent on the network media. Consumers only need to purchase goods through the network and 
complete the transaction. Both buyers and sellers will not care about the existence of tax problems.

\subsection{Characteristics of E-Commerce}

Compared with the traditional form of transaction, e-commerce has its own characteristics, and it is these characteristics that make e-commerce develop rapidly on a global scale.

1) Transaction virtualization.

The virtual nature of transactions is reflected in every aspect of the transaction, such as entity virtualization, transaction site virtualization and transactional goods, service virtualization. In particular, pure e-commerce, from information search, inquiry, negotiation, payment to delivery of goods and after-sales service are all carried out in a virtual network environment. The virtualization of goods and services is reflected in the digitization of products and the electronic way of settlement.

2) Low cost of transaction.

From the point of view of the seller, the transaction relies on the virtual environment. It does not require a fixed product display place like traditional business activities, nor does it need to use paper sales vouchers. Therefore, transaction costs can be effectively reduced. For the purchaser, obtaining purchase information and completing transactions through the Internet can effectively save time and capital costs.

3) Efficient and convenient.

E-commerce is enabling producers and users to communicate and trade through the network to the greatest extent, which can minimize the intermediate links of business activities and improve transaction efficiency.

4) Global scale of the transaction.

The Globalization of the Internet leads to a larger scale of e-commerce market. Buyers can find the goods or services they need all over the world. Sellers can also bring goods and services to all parts of the world through the Internet.

\section{Tax Management Issues Caused by E-Commerce}

With the rapid development of China's e-commerce market, while bringing considerable tax revenue to the country, it has also brought great challenges to China's taxation management work. The e-commerce tax management issues discussed in this paper are mainly for the three forms of B2B, B2C and C2C. From the perspective of tax administration, the impact of e-commerce mainly includes the following aspects:

\subsection{The Impact of E-Commerce on Tax Elements}

The tax element is the specific expression of the tax content. It mainly includes the taxpayer, the tax object, the tax item and tax rate, the tax period and location. Because e-commerce has the characteristics of virtualization, unboundedness, 
digitization, it makes the current taxation elements less restrictive to e-commerce, resulting in a series of problems such as the vague nature of taxation objects and the uncertainty of tax time and place. To a certain extent, it also poses a challenge to tax collection and management [2].

\subsubsection{Object of Taxation Is Difficult to Determine}

The object of taxation is the basis of taxation. At the same time, various taxes are identified by distinguishing the taxable object. E-commerce has changed the nature of products to a certain extent. By using the relevant functions of the Internet, it transforms the products or services originally provided in the form of entities into digital information for transmission, especially some electronic non-physical products, whose real content and actual nature are difficult to define. In traditional physical trade, sales and purchases of goods should be the same, but online buyers can download and duplicate in digital form, making the number of both unequal. The nature of such downloading behavior is also hard to define as selling goods or franchising.

\subsubsection{The Assessable Period and Location for Tax Payment Are Difficult Determine}

The provisions of the tax law on the tax payment period mainly include the occurrence time of the tax obligation, the tax payment period and the period of paying the treasury. Because of the concealment of e-commerce and the uncertainty of trading place and trading time, many difficulties have been brought to the current tax administration in China. Under the environment of e-commerce, it is difficult for the current tax law to determine whether the time of tax obligation is defined by the time of delivery, or by the time of receipt or collection, and whether the place of tax payment is determined by the place where the service takes place or the place where the institution is located. At present, the mainstream view in China is to determine the location of registered transaction server as the tax payment place, and regard the online store itself as a permanent institution, but these views need further discussion.

\subsection{The Influence of E-Commerce on Tax Collection and Management}

\subsubsection{Tax Registration System Is Difficult to Apply}

Detailed Rules for the Implementation of the Law of the People's Republic of China on Tax Administration and Collection clearly stipulates that taxpayers should handle tax registration certificates on time. However, quite a number of C2C self-employed businesses that is, without the approval of the Ministry of Industry and Commerce, business license and without tax registration certificate. In general, they do not have a strong sense of taxation, and the tax authorities have no way to start, and it is even more difficult to implement effective tax administration for taxpayers. Even some enterprises' network sales are not reflected in ledger account at all, and the tax authorities can not verify it, which causes a part of the tax loss. 


\subsubsection{Electronic Transaction Documents Are Hard to Obtain}

Chinese traditional tax collection and inspection methods are based on paper books and vouchers. In the context of e-commerce, the original tax collection and inspection basis has ceased to exist, leaving only digital information. Taxpayers may use multiple encryption technology to cover up their real transaction data, which makes the collection and management of tax authorities more difficult, and the legal effect of giving electronic transaction vouchers appears to be extra important. All these problems have brought great challenges to the tax administration of the tax authorities.

\subsubsection{It Is Difficult to Verify the Accuracy of Tax Returns}

Under the background of e-commerce, due to the concealment of transactions and the digitalization of information, the traditional management mode of tax sources controlled by tickets is no longer applicable to modern e-commerce trade. Most small-scale e-commerce companies have no accounting system at all. Their legal awareness is weak, and they have no willingness to pay taxes on their own initiative. If tax authorities want to collect their transaction information or verify tax data, it is not only heavy workload, but also inefficient. This led to the fact that the Inland Revenue Department was unable to verify the completeness and authenticity of the tax returns [3].

\subsubsection{Tax Inspection Is Hard to Achieve}

Thanks to the convenience of the Internet greatly simplifies the traditional trade process, buyers and sellers do not need face-to-face negotiation, they use the network to complete the entire transaction. However, compared with traditional trade mode, electronic credentials related to Internet transactions can be easily tampered with. In addition, the buyer can also settle accounts through remittance, transfer, Alipay and other ways, making the tax authorities' supervision works that become very complicated, plus taxpayers may deliberately cover up the real data information, which makes the tax inspection work more difficult.

\section{Analysis and Enlightenment of Foreign E-Commerce Tax Policy}

\subsection{Analysis of Foreign E-Commerce Tax Policy}

\subsubsection{US E-Commerce Tax Policy}

The United States is the birthplace of the Internet that is resolutely opposed to the imposition of a new tax on e-commerce and advocates exemption from tariffs. In 1996, the US Treasury Department promulgated that Selected Tax Policy Implications of Global Electronic Commerce, advocated the principle of tax neutrality, and advocated not introducing new taxes on e-commerce. In October 1998, the US Congress passed the Internet Tax Exemption Act, which avoided new taxes on the Internet for three years from October 1998. In 2004, the United States enacted the Internet Tax Non-Discrimination Act, extending the validity of the Internet Tax Exemption Act to November 1, 2007. In 2007, the United 
States quickly announced (the Internet Tax Freedom Act Amendment Act of 2007), and the period for exempting the Internet from taxation was extended for another seven years, which is believed to drive the continued rapid development of the Internet industry throughout the United States. Due to the global advantages of the United States in this regard and based on the consideration of maintaining its economic growth and future strategic position in the world economy, the tax exemption for e-commerce is undoubtedly beneficial to the United States [4].

\subsubsection{EU E-Commerce Tax Policy}

The European Union is one of the early countries to levy taxes on pure e-commerce. From the EU's policy measures on e-commerce, the core content is fairness. E-commerce companies and non-e-commerce companies in EU member states have the same tax burden, and the applicable tax laws are the same. Because the EU believes that all enterprises should be treated equally and fair tax burden, the EU opposed the US e-commerce tax exemption policy early. Since 2003, it has been levied in the form of value-added tax. At present, the EU is required to pay e-commerce value-added tax and import tariffs for e-commerce goods imported from outside, but its export is tax-free. For domestic sales, goods between member states, the value-added tax for e-commerce is levied at the original place of transaction. For online service, the provider does not need to pay taxes, but the user of the service pays taxes. And the foreign units, individuals and businessmen who purchase within the EU must pay the relevant taxes at the place of purchase [5].

\subsubsection{E-Commerce Taxation Policy of the Organization for Economic Cooperation and Development (OECD)}

1) In 1998, the Geneva Conference reached a one-year tariff exemption for full e-commerce goods for Internet transactions.

2) In 1999, at the Paris meeting, it was agreed to adopt the existing tax system to adapt to the trading environment of e-commerce, instead of re-introducing new type of tax. It also makes the tax base fair by the consumption of goods or services and considers the location of the computer server as a permanent organization.

3) In 2000, the OECD (Organization for Economic Co-operation and Development) recommended that the United States should levy taxes on e-commerce and postal sales.

4) In addition to the United States and Australia, the Organization for Economic Cooperation and Development imposes a value-added tax on e-commerce transactions, and is actively exploring the "mutual assistance" type of collection method, that is, the consumer country helps e-commerce companies to collect taxes and to responsible for tax handover.

\subsubsection{United Nations E-Commerce Tax Policy Recommendations}

In 2000, the Human Rights Development Report proposed to levy a Bit tax, and stipulated that 100 cents of e-commerce tax would be levied on 100 units of mail 
greater than 10,000. It is also recommended to use the tax on bit tax to support the development of science and technology in developing countries and narrow the gap in international electronic communication technology. In short, the United Nations' foothold in developing e-commerce taxation policies is to uphold the tax benefits of developing countries.

In 2010, the United Nations called for tax reforms to levy GTS (Goods Service Tax) on consumers who purchased offline and online goods from abroad, but the plan was not approved.

Generally speaking, electronic commerce legislation of other countries has three common characteristics:

1) Development is extremely rapid.

Since the introduction of Digital Signature Law in Utah, dozens of countries, organizations and regions have enacted relevant laws or drafts of electronic commerce in a few years. In particular, the United Nations Commission on Trade Law (UNCITRAL) has played a pioneering and exemplary role in guiding the relevant legislation of e-commerce in various countries in the world in a timely manner. This highly effective legislative measure is rare in the history of world legislation. In contrast, China's response speed is somewhat slow or even lagging behind in this regard. With the continuous expansion of the scale of e-commerce, China should take effective measures as soon as possible to supplement and improve the existing legislation and policies.

2) Compatibility.

With the rapid development of e-commerce and the gradual breaking of national boundaries, any behavior which divorce oneself from the masses and from reality and act blindly in e-commerce legislation is not only a clumsy act, but also a serious impediment to the development of e-commerce and related industries. Therefore, compatibility is one of the first criteria to be considered in e-commerce legislation in various countries. The United Nations Commission on Trade Law (UNCITRAL) has pointed out in its Guidelines on Uniform Rules of Electronic Signatures that "the inherent internationality of electronic commerce requires the establishment of a unified legal system, and the current status of legislation in different countries may pose a risk of impeding its development. "Therefore, China should speed up the pace of tax consultation and cooperation with other countries and organizations in e-commerce in order to achieve a favorable situation of policy integration and mutual promotion with other countries in the world.

3) The formulation of laws in various countries has promptly and forcefully promoted the development of e-commerce, information construction and related industries.

E-commerce has a huge market in China, and its driving effect on social economy and related industries is increasingly obvious. Under this trend, how to use the leverage of taxation to achieve the tax loopholes that block e-commerce and maintain electronic business and related industries have developed in a healthy and orderly manner as a question for the law makers in China. Since the 
commercial application of the Internet, although the major countries and organizations in the world have put forward the norms and regulations that are suitable for the development of e-commerce, but today, fiscal taxation, laws and regulations, information security, market access, and several other issues will continue to be factors that hinder the development of e-commerce for a long time. Taking a comprehensive view of the above-mentioned organizations and national legislation or measures on e-commerce, whether it is to amend and supplement the existing traditional legal norms in order to get the support of the current legal system of e-commerce, or to formulate new legal norms, the ultimate goal they pursue is to establish a secure and standardized legal environment for e-commerce, and to eliminate obstacles in the development of e-commerce. Then we can increase the confidence of enterprises and consumers in e-commerce, and maximize the development of e-commerce and strengthen the effective norms of the state in the field of taxation.

In short, with the globalization of China and the acceleration of the marketization process, it has become an inevitable choice for China to participate in global economic cooperation to construct a perfect e-commerce legal system including tax law.

\section{Suggestions on Establishing E-Commerce Taxation System in China}

\subsection{Making Reasonable Tax Policies for E-Commerce}

China's current tax laws and policies have obviously lacked the binding force for e-commerce. The problems of tax management caused by e-commerce need to be solved and dealt with in a timely manner. In view of the characteristics of paperless e-commerce, it is necessary to supplement and clarify the relevant concepts of various taxes in the current tax law, such as tax time and place involved in e-commerce trade, so as to make e-commerce tax management more standardized and legalized.

\subsection{Building a Multi-Level Tax Monitoring System for E-Commerce}

\subsubsection{Implementation of Classified Electronic Tax Registration System}

For $\mathrm{B} 2 \mathrm{~B}, \mathrm{~B} 2 \mathrm{C}$ and $\mathrm{C} 2 \mathrm{C}$, classified electronic tax registration system should be implemented. Promoting this system can not only reduce the threshold of business registration of e-commerce enterprises, and simplify the registration process, but also supplement and standardize the tax registration system of e-commerce enterprises.

Because the business scale of $\mathrm{B} 2 \mathrm{~B}$ e-commerce enterprises and some $\mathrm{B} 2 \mathrm{C}$ e-commerce enterprises are generally relatively large, accounting system is relatively perfect, and tax registration has generally been carried out. Therefore, such enterprises need not go through tax registration again, they only need to make paper tax registration certificate into an electronic form approved by tax authorities. $\mathrm{B} 2 \mathrm{C}$ e-commerce enterprises and $\mathrm{C} 2 \mathrm{C}$ individual e-commerce enterprises 
that have registered for taxation must register for Industry and Commerce in accordance with the original regulations, and then apply for tax registration. For some $\mathrm{C} 2 \mathrm{C}$ individual e-commerce enterprises that do not meet the requirements for industrial and commercial registration, so they only need to apply the tax registration.

\subsubsection{Promoting E-Commerce Special Invoice}

With the continuous development of e-commerce, the volume of its transactions is also increasing. After forcing e-commerce enterprises to register in accordance with the law, we can promote the use of e-commerce special invoices throughout the country. In order to ensure the implementation of this policy, China can standardize the process of e-commerce invoice issuance to achieve the effect, that is, when the buyer and seller negotiate and place an order, the buyer pays the money to the third-party platform, and then the seller is forced to submit the invoice information involved in the exchange to the third-party platform, the platform's settlement. The system needs to check the payment and invoice information. After checking and verifying, the system automatically transfers the transaction amount to the seller's account. In addition, the transactions conducted by e-commerce through the third-party trading platform need to check the accounting information monthly and give the seller timely feedback.

\subsection{Training Professional Electronic Tax Collection and Management Personnel}

With the rapid development of e-commerce, many challenges have arisen in the tax work related to it, and higher requirements have been put forward for the quality and knowledge structure of tax personnel. It requires tax cadres not only to have solid knowledge of tax theory and work capacity, but also to be proficient in computer network knowledge and information technology. Only by truly understanding the basic operation process of e-commerce, can we make better use of information technology to strengthen the tax source monitoring of e-commerce. In addition, through the development and promotion of online tax declaration system to serve all types of taxpayers, we can simplify the declaration process, and save the labor costs. At the same time, the administrative efficiency can also be improved. In addition, tax authorities also need to attach great importance to and strengthen the training and introduction of such talents in order to ensure the development of e-commerce tax management.

\subsection{Strengthen International Tax Cooperation and Coordination}

With the trend of economic globalization becoming more and more obvious, the international tax disputes and changes in the pattern of interests are also extremely fierce. The international taxation issues involved in e-commerce, such as tax jurisdiction and tax benefit distribution, can be resolved by strengthening international tax cooperation and coordination. Although the tax policy of e-commerce will vary greatly from country to country, the premise of maintain- 
ing national tax sovereignty is the same. Only by strengthening international tax cooperation and coordination can we obtain e-commerce-related tax information on a larger scale, in order to broaden the access to e-commerce transaction information to a greater extent, and gradually establish a new international taxation guideline in disputes and discussions, which will reduce the possibility of international tax avoidance and double taxation to a greater extent.

From the popularity of $\mathrm{C} 2 \mathrm{C}, \mathrm{B} 2 \mathrm{~B}$ and $\mathrm{B} 2 \mathrm{C}$ to the exploration and guidance of $\mathrm{O} 2 \mathrm{O}$ and the promotion of various network marketing, all of them reflect the charm and power of the Internet, and are also showing the importance of e-commerce in life and foreshadowing the future social development trend. Under this background, e-commerce taxation is not a new topic, it has a broader prospect in the future. Taxation is the eternal theme of the country ruled by law and civilization. Because of virtualization of taxpayer, uncertainty of taxpayer's place and time, and electronic transaction voucher, e-commerce taxation makes the traditional taxation legal system unable to adapt. Taxation is the main way for a modern country ruled by law to obtain financial revenue. The internal affairs and diplomacy of a country depend on the support of taxation. In the era of e-commerce, under the background of building a society ruled by law, it is urgent and important to improve the legal system of e-commerce taxation. On the basis of explaining the general problems of e-commerce taxation, this paper analyses the impact of e-commerce on taxation system, and puts forward the existing problems of e-commerce taxation in China based on foreign experience. In the consideration of perfecting the tax system, we should clarify the value orientation and improve our current tax management system, also solve the conflicts between legal systems and redefine some tax concepts. E-commerce is bound to appear a variety of new content, and the tax law can only adapt to the development of the times by constantly amending the outdated provisions.

\section{Conflicts of Interest}

The author declares no conflicts of interest regarding the publication of this paper.

\section{References}

[1] Liu, J.H. and Wang, X.P. (2017) Study of Tax Law Problem and Solution in Internet plus E-Commerce. Journal of Central South University (Social Science), 3, 70-78.

[2] Fu, A.Y. (2014) Thoughts on the Development of e-Commerce in China and Its Tax Legal Issues. China Business \& Trade, 17, 115-116.

[3] Zhu, J. (2013) Tax Losses of Chinese E-Commerce and Its Control Measures. Collected Essays on Finance and Economics, 2, 42-49.

[4] Chaffey, D. (2015) Digital Business and E-Commerce Management. Pearson, New York, 5-15.

[5] Wang, X.D. (2018) The Challenge of e-Commerce to Tax Collection and Management System. CO-Operative Economy \& Science, 2,186-187. 